\title{
Household Unit Factors and Efficient Electricity Use: A Review of Households in Nakuru Town Housing Estates
}

\author{
Maina Kairu ${ }^{1, *}$, Oyugi Tobias ${ }^{1}$, John Mironga ${ }^{2}$ \\ ${ }^{1}$ Department of Education and External studies, University of Nairobi, Nairobi, Kenya \\ ${ }^{2}$ Department of Geography, Egerton University, Nakuru, Kenya
}

Email address:

mainakairu@yahoo.com (K. Maina),koyugibft@gmail.com (T. Oyugi),john.mironga@gmail.com (J. Mironga)

\section{To cite this article:}

Maina Kairu, Oyugi Tobias, John Mironga. Household Unit Factors and Efficient Electricity Use: A Review of Households in Nakuru Town Housing Estates. International Journal of Economics, Finance and Management. Vol. 3, No. 2, 2015, pp. 68-77. doi: 10.11648/j.ijefm.20150302.11

\begin{abstract}
The purpose of the study was to relate household unit factors and efficient electricity energy use within the Nakuru town residential houses. The study adopted a correlational research design and conducted a correlational analysis to understand the influence of household unit structure on efficient electricity use. Primary data was collected on household unit structure and efficient electricity use through structured questionnaires and interviews. Descriptive statistic was employed in describing the individual variables in this study. This study revealed that household factors influence efficient use of electricity. However, this influence is not statistically significant. The study recommends that household structural factors should be considered in decisions related to use of energy. The findings are expected to be beneficial to the housing sector stakeholders, KPLC and the Government since the recommendations proposes appropriate measures that would increase efficiency and conservation in the usage of electric energy. The County Government of Nakuru as well as other counties may adopt these recommendations in their strategies and policies that relate to sustainable electric energy use. The study recommends further study on complementary energy sources to electricity and how use of such sources of energy can improve livelihood of households, productivity and sustainability among organizations.
\end{abstract}

Keywords: Household Unit Factors, Efficient Electricity Use, Nakuru Town Housing Estates

\section{Introduction}

\subsection{Background of the Study}

The millennium development goal number seven envisages developing nations to undertake sustainable developments. Sustainable development has various dimensions, but the study dealt on energy sector sustainability and of particular interest electric energy. The Kenya vision 2030 envisions having Kenya as a middle income nation by the year 2030, where industrial activity is set to grow. Industrialization would require a substantial amount of energy especially electric energy. In line with industrialization, there is expected to be a higher demand for housing to cater for the expected growing urban population occasioned by the industrial activity. The current situation on household consumption pattern, conservation, adherence to specified standards of electricity use within the residents of $\mathrm{MCN}$ is not documented.

$\mathrm{MCN}$ and the private sector lack or have very scanty information on the mentioned issues to inform them of future improvements on electricity installations that are efficient and effective. The code of regulation of the Government of Kenya under section $\mathrm{L}$ that deals with electrical issues in Government houses sub sections (2),(3) and (4) stipulates and gives guidance on requirements for electrical appliances ,lighting and switching off of the same. It is worth noting that MCN is under the Ministry of Local Government which is therefore bound by the said regulations.

Unlike other Government Quarters which are inhabited by serving Government officers, these Government houses are inhabited by the general public whose knowledge and awareness of the stated standards has not been explored, therefore it is anticipated that this study will give an insight into the level of understanding among the tenants of the existence of the mentioned standards. Kenya Power and Lighting Company had sometimes back distributed free energy saving bulbs to many households. The problem is why is it that a sizeable number of households still cling to the tungsten bulbs/incandescent bulbs thereby reversing 
anticipated gains in conservation of electrical energy.

\subsection{Significance of Study}

The study findings are expected to be significant to the energy sector in Kenya. It is expected to evaluate whether energy efficiency is practiced in majority of households and weather household structure influence such practices. It is expected to inform government's policies as regards electricity as an important resource in planning for the macro economy and environmental sustainability of the power sector. The study is further expected to give recommendations on the appropriate energy policy that would encourage electric energy efficiency. The study findings were hoped to provide a better understanding of modern households' electricity use patterns. The findings the research will contribute to a better understanding of the present problems and provide solutions to the effective use of electric energy.

\subsection{Research Objectives}

This study was guided by three objectives:

1. To establish the influence of number of occupants on efficient use of electric energy among Nakuru town housing estates

2. To establish the influence of age of household members on efficient use of electric energy among Nakuru town housing estates

3. To establish the influence of house size on efficient use of electric energy among Nakuru town housing estates

\subsection{Research Hypothesis}

Ho1: Number of occupants has no influence on efficient use of electric energy among Nakuru town housing estates

Ho2: Age of household members has no influence on efficient use of electric energy among Nakuru town housing estates

Ho3: House Size has no influence on efficient use of electric energy among Nakuru town housing estates

\subsection{Conceptual Framework}

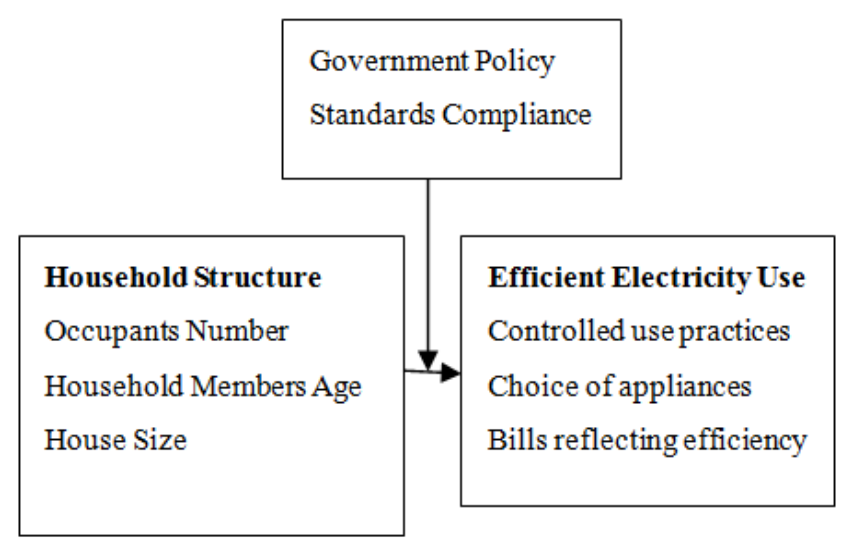

Figure 1. Conceptual Framework.

\section{Literature Review}

\subsection{Demand and Supply of Electricity}

The dynamics of supply and demand for electric power forms a basis for the conservation of the scarce but expensive resource in Kenya. There have been serious issues of ration in many estates as a result of the vagaries of weather as Kenya normally relies on hydro power. According to a report by Kenya Power, there were more than $1,500,000$ customers who consumed over 5,432 gig watt hours of electricity in the financial year 2008/9 (AFREPREN, 2005).

According to KPLC Annual Report of 2007, during the year 2008/9, the maximum daily electricity peak demand recorded was 1,072 MW. The electric power sector in Kenya relies largely on renewable energy sources such as hydro power and geothermal, with the supplement of imported fossil fuels to meet the increasing demand of electricity. In 2008, total generation reached 6,460 million kilowatt hours (MkWhs), comprising its main energy sources from hydroelectric power (50\%), oil (33\%) and geothermal (16\%). A hydro-led power sector frustrated Kenya with the production declined of $9 \%$ due to drought. Oil-fired power plants play an auxiliary role and increased the generation by $23 \%$ from 2007 to fill in the shortage of hydroelectric power according to an increasing dependency on imported oils that may raise electricity prices and affect other economic activities negatively. Geothermal is gaining attention with the potential of $4000 \mathrm{MW}$ capacities unexploited in Kenya (KPLC Annual Report, 2007).

According to Balla (2006), to secure the reliable supply of utilities, Kenya plans to build more power plants with the total capacity of more than $2000 \mathrm{MW}$ from the variety of energy sources including geothermal, hydro, wind, coal, and diesel by 2015. National annual electricity retail sales amounted to 4964 MkWhs in 2007 and the steady growth averaged 5.7\% for the last 6 years. Such increasing demand was led by industrial and commercial sectors $(71 \%)$ followed by households $(23 \%)$. However, electricity serves only about $15 \%$ of households including half of urban households and $4 \%$ of rural residences (KIHBS, 2007).

According to Wamukonya, (2007), urban households use electricity and kerosene for lighting, while dominant rural dwellers illuminate rooms with kerosene lamps. In light of the fact, there was need to evaluate how the electricity energy was utilised in urban settings since in both rural and urban households, the electricity connectivity falls well below the $20 \%$ threshold. A research in Nakuru Municipality was hoped to be a fair representative sample that can be generalized in other urban centres in Kenya.

\subsection{Energy Saving Measures}

In a world with limited energy resources, it was essential that consumers learn how to conserve electricity. This helped to save money and conserving the environment. In that regard households can make a difference by using the available power efficiently according to Sanghvi \& Barnes (2001). 
According to KPLC report on efficient electricity use (2011), there are a number of measures that can be taken to improve energy consumption in homes. These measures based on the

lighting component of the households include the use of Compact Fluorescent Lamps (CFLs) which last longer than the ordinary incandescent lamps. CFLs also generate less heat which means less cooling bills. All in all, CFLs can save up to $80 \%$ of the energy used on lighting. The household user is supposed to ensure that all lighting fixtures are cleaned regularly as dust on the surface impairs the light output. Households should use electronic ballasts which are more efficient than the conventional magnetic ballasts for fluorescent tube lighting.

According to Nandi \& Bose, (2010), the electronic ballast uses up to $40 \%$ less energy, is flicker free and eliminates hum. Electronic ballasts also generate less heat thus lowering the cooling bills. Enhanced use of timers to turn security lights on in the evening and off in the morning to ensure the lights were switched on only when necessary as a good conservation measure. Motion sensors, where possible, were important to ensure lights were on only when required. Additionally, you can utilise photo sensors for security lighting to automatically turn your light on at night and off during the day. Turning off lights when they not in use, even just for a few minutes can save electricity every time they are turned off, no matter how short the duration. Separating the lighting circuit to ensure that only the required lighting was switched on designing houses that maximize on natural sunlight during the day are good conservation measures whose evaluation of their use was important in domestic households (O'Sullivan \& Barnes, 2006). There is now a new concept of eco-friendly houses that use very minimum energy, they have solar panels, natural lighting is maximized and wind power generators are also installed.

Energy is also utilized in cooking according to Basa, (2009), there was need for the enhanced use of pressure cookers which cut food preparation time to one-third of that required by conventional methods. Households are expected to use pots and pans with flat bottoms to enhance effective heat transfer since they will be heated uniformly. An electricity user should make sure that the pan matches the size of the cooker element. The effective use of electricity also entails turning off the oven, surface units or burners shortly before food has completed cooking to make use of residual heat. The power user should preheat the oven only when necessary and only for the required time according to Daraga, (2005). There is need to use the oven to capacity by cooking more than one dish or one meal at a time. As a good measure of electricity utilisation, a user should not open the oven door unnecessarily; every time the oven door is open, or there is need to check the cooking, there is a heat loss of about $20 \%$ of the heat since oven temperature drops $25-30^{\circ} \mathrm{C}$ every time you open the oven door.

Daraga (2005) further advises that there is need to thaw frozen foods first to reduce cooking time and use only enough water to cover the food being cooked. Covering the cooking pan and once the food boils; turn down the heat to the minimum was a good conservation of power procedure. One should use a microwave oven for small quantities of food as it is quicker than using the cooker or the oven. Another procedure that efficiently utilises electricity was when an electric kettle was used to boil water instead of the cooker and using a toaster instead of the grill to make toast (KPLC, 2011).The study therefore aimed at investigating the above issues at the household level in Nakuru Municipality, in a bid to understand the extent people go into conserving energy and whether there are in line with modern ways of conserving energy.

A Republic of Kenya Report on Kenya's energy demand (2001) says that as a safety measure, the consumer should use the kettle to boil small amounts of water as it uses less energy. When using the kettle, only boil the amount of water you need. As a conservation measure, however, to cover the element to avoid damaging the kettle. The use of electricity kettle should be limited to a kettle with a water level indicator which makes it easier to measure the quantity of water needed.

In a study on consumer behaviour and energy conservation, Ester, (1985) calls for proper refrigeration measures that a user of a fridge should always match the size of the fridge to the household needs. A medium sized refrigerator (rated 150 watts) uses $36 \mathrm{KWh}$ per month which costs approximately KShs.465. Placing the fridge away from heat sources such as direct sunlight, ovens and other appliances and ensuring there is adequate ventilation at the back, sides and top at the very least, two inches of space all around should ensure efficient exchange of heat. Adjustment should be done to the thermostat to maintain correct temperature. The most efficient temperature for a fridge was between $3{ }^{\circ} \mathrm{C}$ and $5.5^{\circ} \mathrm{C}$. Cooler temperatures are not necessary and incorrect temperature settings cause an increase in energy consumption. A consumer should keep the coils at the back dust-free as accumulation of dust on condenser coils as this can increase energy consumption by up to $30 \%$.

Kasulis, (1981) calls for ensuring that the door seals are in good shape as a methodology for conservation. If the door doesn't seal well, cold air escapes and lets in warm air which the fridge uses more energy to cool. The consumer is expected to minimize the number of time the fridge opens. Open/close habits waste 50-120 KWh of energy a year which accounts for $10-24 \%$ of the total energy consumption of the fridge.

Kasulis et al (1981) further calls for proper utilisation of entertainment appliances since a number of electrical appliances cannot be completely switched off without unplugging the device or turning it off at a power strip. When that is not done, the appliances continue to draw power. The power consumption is known as 'stand-by power'. A television left on stand-by can use up to $10 \%$ more power. Switching off your DVD player can save up to $50 \%$ of the energy it consumes. Switching off your music system at the set or unplugging it can save up to $50 \%$ on energy consumed.

A KPLC (2004) guide on electricity utilisation gives the corresponding savings that can be derived from using an electrical appliance appropriately. For example, an air 
conditioner rated 1200 watts that is on 12 hours a day will use $324 \mathrm{KWh}$ a month which will cost approximately KShs.4, 212 $95 \%$ of the energy used by a washing machine goes to heat the water. You could save a lot by just lowering the temperature of the water. Reducing the wash temperature at a full load from $60^{\circ} \mathrm{C}$ to $40^{\circ} \mathrm{C}$ can save up to $110 \mathrm{KWh}$ per year. Wash at $40^{\circ} \mathrm{C}$ or lower wherever possible. A typical washing machine uses $5.24 \mathrm{KWh}$ of electricity per wash load and costs about KShs. 68 per wash (when washing with hot water). Making 15 loads of washing per month will cost approximately KShs. 1,020. Washing with cold water uses $0.26 \mathrm{KWh}$ per load and costs only about KShs. 3.38. When making a purchase, opt for an energy efficient washing machine. Choose a front loading model which uses $63 \%$ less water on average. Firstly, iron fabrics that require lower temperature and work up to those requiring higher heat. Using a 1,000 watts iron box for 1 hour per day will use $30 \mathrm{KWh}$ per month costing you about KShs. 390.Water heating ensures that hot water tanks and pipes are well insulated to avoid loss of heat. Repair leaking pipes or taps to prevent loss of hot water; every 30 drops per minute from a hot water tap costs you around $18 \mathrm{KWh}$ per month at roughly KShs. 234 according to KPLC (2010).

The GoK, Energy Act (2004) stipulates that Customers should keep their meters in proper order for purposes of ascertaining the value of the supply and correctly registering that value (Section 85 of the Energy Act). Under the law (GOK,2004), the Kenya Power had the right to access and the liberty to take off, remove, test, inspect and replace any meter at all reasonable times provided prior notice was given to the customer.

\subsection{Complementary Energy Sources}

In Kenya, energy resources comprised commercial and non-commercial. Commercial energy mainly comprises of petroleum products and electricity, while non-commercial comprise of biomass, and to a lesser extent solar energy, wind power and biogas. From the National Energy Matrix, total final energy consumption in Kenya in 2009 was $14,353.8$ thousand tonnes of oil equivalent while the total primary energy supply was 18,215.99. Petroleum fuel accounts for about $28.57 \%$ of the total final energy consumption while electricity and combustible renewable accounts for about $3.11 \%$ and $67.65 \%$ of the total final energy consumption. The energy sector contributes about $9.49 \%$ to GDP with the petroleum sector, electricity and fuel wood sector contributing $8.4 \%, \quad 0.6 \%$ and $0.4 \%$ respectively.(MOE,2009).The GDP per unit of oil equivalent is PPP US\$ 2.98 compared to that of Botswana of US\$ 12 and Tanzania US\$ 2.53 .

The uses of LPG at homes, educational and health institutions have risen from slightly over 40 thousand metric tons in 2003 to 80 thousand metric tons in 2008 (KIPPRA, 2010). Motor gasoline which is mostly used in the transport of passengers and goods may not have made any remarkable growth owing to the efficiency of the vehicles entering the domestic market, in spite of the rise in numbers.

Automotive gas oil, the dual purpose fuel consumed by transport and agriculture, has a six fold rise between 2003 and 2008. Other products which recorded increased consumption include lubricating oils, as proof of the growth of transport vehicles and machinery for use in agriculture and manufacturing industries. Illuminating kerosene the most popular fuel for use by households in lighting and cooking used about 300 thousand cubic metres in 2008 as compared to about 200 thousand cubic metres consumed in 2003(KIPPRA,2010).

The analysis showed that about $70 \%$ of the consumers use biomass while $30 \%$ use other fuels. This supports well known studies that biomass provides $70 \%$ of the energy requirements (Kituyi, Kamfor 2002). The study showed kerosene to be mostly used for lighting (52\%) while biomass was widely used for cooking $(60 \%)$. The survey data showed that users of charcoal and fuel wood in Nairobi had to travel on average 0.59 and 6.44 kilometres respectively to access the fuel they need. With an exception of the transport fuels, average monthly consumption per household is high for electricity (386.01 Mega Joules) compared to the other fuels. The energy budget shares for households differ across the provinces, fuels as well as location, either rural or urban. Fuel wood has the highest energy budget share on average for both rural $(11.6 \%)$ and urban $(9.34 \%)$ compared to the other fuels (Kituyi \& Kamfor, 2002)

The ultimate source of energy for living organisms is the Sun of course. It supplies incredible amount of energy to the Earth's surface.(Southwick 1976). The total amount of solar energy striking the earth's surface each day is equivalent to the energy in 684 billion tons of coal $(6.84 \times 10 \times 11)$ tons. This is sufficient energy to produce light energy equivalent to that supplied by over 1,000,000 watts for each acre of ground. The solar energy striking the surface

of the United States every 20 minutes is sufficient to meet the country's entire power needs for one year, if it could be harnessed (Southwick 1976). The study would endeavour to investigate why then is solar energy not popular yet it seemed to be the most cost effective, efficient and environmental friendly.

\subsection{Rational Action Theory of Choice}

This study is founded on the rational action theory as popularly referred as the choice theory, the theory was propounded by Gary Stanley Becker (1930) an American economist known for arguing that many different types of human behaviors can be seen as rational and utility maximizing. The "rationality" described by rational choice theory is different from the colloquial and most philosophical uses of the word. For most people, "rationality" means "sane," "in a thoughtful clear-headed manner," or knowing and doing what's healthy in the long term (Christina, 2003).

Rational choice theory uses a specific and narrower definition of "rationality" simply to mean that an individual acts as if balancing costs against benefits to arrive at action that maximizes personal advantage. The basic idea of rational choice theory is that patterns of behavior in societies reflect the choices made by individuals as they try to maximize their 
benefits and minimize their costs. In other words, people make decisions about how they should act by comparing the costs and benefits of different courses of action. As a result, patterns of behavior will develop within the society those results from those choices (Christina, 2003).

Michael (2002) argued that the idea of rational choice, where people compared the costs and benefits of certain actions, is easy to see in economic theory. Since people want to get the most useful products at the lowest price, they would judge the benefits of a certain object (for example, how useful is it or how attractive is it) compared to similar objects. Then they would compare prices (or costs). In general, people would choose the object that provides the greatest reward at the lowest cost. In that light therefore, how rational the tenants of Nakuru Municipal Council houses could be depend on the cost, level of awareness and the practices that they exhibit as consumers of electricity energy.

\section{Research Methodology}

\subsection{Research Design}

This study adopted correlational research design. A correlational design was chosen to help bring an understanding of the influence of household structure on sustainable use of electric energy. However, the study was not limited to correlational analysis. Descriptive statistics was used to explain household structure and efficient of electric energy.

\subsection{The Target Population}

This study targeted the 5434 houses owned by the former Municipal Council of Nakuru. The households are categorized into three groups as shown in table 1 .

Table 1. Distribution of the Nakuru Municipal Council Houses.

\begin{tabular}{ll}
\hline House Category & Number of Households \\
\hline Three Bedrooms & 15 \\
Two Bedrooms & 110 \\
One bedroom & 32 \\
Single Room/Bedsitter & 3522 \\
Total Population & 5,434 \\
\hline
\end{tabular}

Source: MCN, (2012)

\subsection{Sampling Procedure}

Stratified sampling was also used to select representative households that were involved in the study. However, the respondents were selected using simple random sampling. According to the Universal Accreditation Board (2003), for a population of $n$ with $95 \%$ confidence interval and a margin of error of $+/-5 \%$, the appropriate sample size can be derived, the sample size so derived for this study was 358 .Households. Based on this and taking into account the possibility of non-response from some respondents when the data was collected, there was the option of taking some sample residential houses or incorporating data from the entire population.

\subsection{Data Collection}

Structured questionnaires were used to collect primary data. The questionnaires were given to the respondents after which they were picked for analysis. To ensure the qualitative data is obtained, validity of the instruments was ensured thorough examination of existing literature to identify conceptual dimensions and appraisal of the instrument by a panel of power and energy consumption experts and other research experts including my supervisor. Similarly, the reliability of the research instrument was improved through the use of the split-half reliability procedure where the researcher administered the entire instrument to a sample of respondents during the pilot test and calculated the total score for each randomly divided half i.e. odd and even numbered items of the questionnaire. Muma et al. (2014) define reliability as the measure of the degree to which a research instrument yields consistent results or data after repeated trials. A reliability coefficient between the two total scores was calculated using the Spearman-Brown property tool. According to Fraenkel \& Wallen (2000) if the results produce a reliability coefficient of $>0.7$ the instrument will be considered reliable.

The formula for reliability is as shown below:

$$
r e=\frac{2 r}{1+r}
$$

Where:

re - Reliability

$2 \mathrm{r}$ - correlation coefficient of $1^{\text {st }}$ half

$1+r$ - correlation coefficient of $2^{\text {nd }}$ half

The results yielded a reliability coefficient of above 0.5 to 0.7 therefore, the instrument was considered reliable for this study.

\subsection{Data Analysis}

After data collection, the collected data was coded into SPSS version 21 and checked. The data was then analyzed. Descriptive statistics was used to describe household structure and efficient use of electric energy. To establish the influence of household structure on efficient use of electric energy, the study adopted a correlational test on the two variables. The results were presented using tables.

\section{Discussion}

\subsection{Number of Occupants}

Respondents were asked to state the number of occupants in the household. This question was strategic in the investigation of conservation of energy. It is easy to assume that the more the occupants the higher the possibility of inefficient use of electricity. The findings were that those who had 1-3 occupants constituted $46.9 \%$, those who had between $4-6$ occupants were $42.6 \%$ while those with above 7 occupants were $10.5 \%$. These findings correspond with the preceding findings that those in single rooms also had the lowest number of occupants. A probable reason may be that it is practically 
impossible for a single room to accommodate more than seven occupants.

\subsection{Types of Lighting Fittings in Use}

For the study to effectively evaluate whether the respondents understand and practice best practices in electricity usage a question was posed with choices of the kind of light fitting they used. The study found out that $47.5 \%$ of respondents use energy saving bulbs, Tungsten bulbs accounts for $34.1 \%$ while florescent bulbs $18.0 \%$.. The rating of energy efficiency is such that the most economical of the three is the Energy saving bulb, followed by the Fluorescent bulb and finally the most inefficient is the Tungsten or Incandescent bulb. The study therefore reveals that a sizeable percentage of household still use Tungsten bulbs which is considered in efficient (34.1\%) and their market price is lower compared to the other two types of bulbs. The high percentage of use of energy saving bulbs may be attributed to the intervention by KPLC.

\subsection{Type of Electrical Appliances Commonly Used in Households}

The study shows the most used electrical appliance by households is Television with the highest percentage of $87.9 \%$, followed by the Transmitter Radio at $74.4 \%$, the DVD at $70.5 \%$ is also another favorite appliance probably in line with the age bracket where mostly the youth dominate. Electric iron box also ranked high in appliances commonly used at $57 \%$. Others are listed in the table 2. The significance of investigating the appliances commonly used was to document how electricity is used in households. This was an effort to establish the popular appliances and the current trends, which may be of benefit to other researchers.

Table 2. Types of Electrical appliances used among households.

\begin{tabular}{lll}
\hline & Frequency & Percent (\%) \\
\hline LIGHTINGS & & \\
Tungsten bulbs & 104 & 34.1 \\
Energy saving bulbs & 145 & 47.5 \\
Fluorescent bulbs & 55 & 18.0 \\
APPLIANCES & & \\
Television & 268 & 87.9 \\
DVD & 215 & 70.5 \\
Electric cooker & 41 & 13.4 \\
Refrigerator & 98 & 32.1 \\
Microwave & 50 & 16.4 \\
Toaster & 40 & 13.1 \\
Electric kettle & 49 & 16.1 \\
Electric iron & 174 & 57.0 \\
Hot water dispenser & 32 & 10.5 \\
Immersion water heater & 77 & 25.2 \\
Instant shower heater & 34 & 11.1 \\
\hline
\end{tabular}

\subsection{Conservation of Energy}

Respondents were asked whether using flat based pan as opposed to rounded base pan had any effect in conservation of energy. The study found out that $55.4 \%$ agreed that conservation of energy can be achieved by using flat base pan and $44.6 \%$ did not agree. Those who agreed are aware that indeed using a flat based pan conserves energy as opposed to the rounded base which losses heat due to the smaller surface area in contact with heat source.

Respondents were asked whether having the refrigerator door seals intact had any effect in conservation of energy. The study found out that $68.2 \%$ agreed that conservation of energy can be achieved by having the refrigerator door seals intact and $31.8 \%$ did not agree. Those who agreed are aware that indeed having refrigerator door seals intact conserves energy as air does not get in and out of the fridge thus ensuring that little energy is used to cool items.

Finally respondents were asked whether using pressure cooker as opposed to conventional sufuria had any effect in conservation of energy. The study found out that $77 \%$ agreed that conservation of energy can be achieved by using pressure cooker and $23 \%$ did not agree. Those who agreed are aware that indeed using a pressure cooker conserves energy as opposed to the conventional. When food is cooked under pressure it takes a shorter time to cook as opposed to when it is cooked under normal atmospheric pressure. There pressure cookers take a short time to cook and therefore conserve energy.

\subsection{Kenya Power and the Government Consumer Sensitization}

A statement was posed to the respondents that the Kenya Power and the Government has fully sensitized consumers on best practices as regards usage of electricity in households. The study revealed that $28.5 \%$ strongly disagreed with the statement, $27.5 \%$ disagreed, $18.7 \%$ were not sure, $19.7 \%$ agreed, and 5.6\% strongly agreed. The finding is that $56 \%$ disagreed with the statement, thus it means that majority feel the Government and Kenya Power has not sensitized consumers on best practices.

Table 3. KPLC \& G.O.K consumer sensitization

\begin{tabular}{lll}
\hline Response & Frequency & Percent \\
\hline Strongly agree & 17 & 5.6 \\
Agree & 60 & 19.7 \\
Not sure & 57 & 18.7 \\
Disagree & 84 & 27.5 \\
Strongly disagree & 87 & 28.5 \\
Government Measures on conservation & & \\
Biogas promotion & 2 & 5.6 \\
Energy saving bulbs & 12 & 33.3 \\
Power Rationing & 19 & 52.8 \\
Sustainable power generation & 3 & 8.3 \\
\hline
\end{tabular}

\subsection{Response on Government Measures in Electricity Conservation}

The respondents were asked to state what measures they thought the Government should put in place to assist them in electricity conservation. The respondents mentioned that the government should introduce power rationing 52.3\%; should supply free energy saving bulbs $33.3 \%$; it should promote use of alternative sources of energy such as solar by removing taxes on the same $8.3 \%$; it should encourage and popularize the use of biogas where applicable $5.6 \%$ it should also put in 
place measures to generate more sustainable power generation methods such as geothermal, wind and solar power.

\subsection{Compliments to Electricity Energy}

Knowledge of existence of other compliments to electricity energy was put to test. Respondents were asked whether they knew of any other compliment to electricity energy. A majority of $70.8 \%$ of the respondents believe that there are other forms of energy that can or are used in the household while $29.2 \%$ do not know of any. The respondents were asked to name any other compliment to electricity that they were aware of, $40 \%$ mentioned solar energy, $16.4 \%$ cited biogas, while $12.7 \%$ mentioned candles which can be categorized as biomass, table 4 below shows the responses obtained.

Table 4. Compliments to Electricity.

\begin{tabular}{lll}
\hline Response & Frequency & Percent (\%) \\
\hline Knowledge on compliments & & \\
YES & 216 & 70.8 \\
NO & 89 & 29.2 \\
Type of source of energy & & \\
Solar & 122 & 40 \\
Candle & 39 & 12.7 \\
Charcoal & 17 & 5.6 \\
Geothermal & 20 & 6.6 \\
Biogas & 50 & 16.4 \\
\hline
\end{tabular}

\begin{tabular}{lll}
\hline Response & Frequency & Percent (\%) \\
\hline Wood & 13 & 4.2 \\
Coal & 3 & 1 \\
Lamps & 30 & 9.8 \\
Wind & 9 & 3 \\
Water & 8 & 2.6 \\
Generators & 13 & 4.3 \\
LPG & 10 & 3.3 \\
Fuel & 11 & 3.6 \\
Lanterns & 8 & 2.6 \\
Others & 5 & 1.6 \\
\hline
\end{tabular}

\subsection{Preferred Compliments to Electricity}

Respondents were asked which complimentary energy they preferred to use; Solar energy was found to be preferred as a compliment of electricity by a majority of $88.9 \%$ while the rest $11.1 \%$ said they did not prefer solar; Kerosene was found to be preferred by $60.3 \%$ of the respondents while $39.7 \%$ did not prefer kerosene; The majority of respondents $80.3 \%$ preferred charcoal and while $19.7 \%$ did not prefer charcoal as a compliment to electricity; The respondents who said they preferred LPG were $50.5 \%$ while $49.5 \%$ did not consider LPG as a compliment to electricity.

\subsection{Relationships between Level of Education and Conservation}

Table 5. Correlations between Level of education and Knowledge on method of conservation, Awareness of Standards and Applications of standards.

\begin{tabular}{|c|c|c|c|c|c|}
\hline & & Education & Method of Conservation & Awareness of Standards & Application of Standards \\
\hline \multirow{3}{*}{ Education } & Pearson Correlation & 1 & -0.1 & -0.07 & $-.174^{* *}$ \\
\hline & Sig. (2-tailed) & & 0.083 & 0.22 & 0.002 \\
\hline & $\mathrm{N}$ & 305 & 304 & 305 & 305 \\
\hline \multirow{3}{*}{$\begin{array}{l}\text { Method of } \\
\text { Conservation }\end{array}$} & Pearson Correlation & -0.1 & 1 & -0.085 & -0.08 \\
\hline & Sig. (2-tailed) & 0.083 & & 0.139 & 0.163 \\
\hline & $\mathrm{N}$ & 304 & 304 & 304 & 304 \\
\hline \multirow{3}{*}{$\begin{array}{l}\text { Awareness of } \\
\text { Standards }\end{array}$} & Pearson Correlation & -0.07 & -0.085 & 1 & $.582^{* *}$ \\
\hline & Sig. (2-tailed) & 0.22 & 0.139 & & 0 \\
\hline & $\mathrm{N}$ & 305 & 304 & 305 & 305 \\
\hline \multirow{3}{*}{$\begin{array}{l}\text { Application of } \\
\text { Standards }\end{array}$} & Pearson Correlation & $-.174^{* *}$ & -0.08 & $.582^{* *}$ & 1 \\
\hline & Sig. (2-tailed) & 0.002 & 0.163 & 0 & \\
\hline & $\mathrm{N}$ & 305 & 304 & 305 & 305 \\
\hline
\end{tabular}

**. Correlation is significant at the 0.01 level (2-tailed).

The following can be deduced from the above table; that there is a negative weak (small) correlation between level of education and knowledge in conservation of electric energy. $\mathrm{R}(305)=-0.1, \mathrm{p}<0.083$; that there is a weak correlation between the level of education and awareness of existing standards regulation electrical usage, $\mathrm{r}(305)=-0.70, \mathrm{p}<0.220$. and finally that there is a negative and weak correlation between the level of education and application of standards. $\mathrm{r}(305)=-0.174, \mathrm{p}>0.002$

Table 6. Appliances on when not needed * Number of Occupants.

\begin{tabular}{|c|c|c|c|c|c|c|}
\hline & & & \multicolumn{3}{|c|}{ Number of Occupants } & \multirow{2}{*}{ Total } \\
\hline & & & $1-3$ & $4-6$ & $>7$ & \\
\hline \multirow{8}{*}{ Appliances on when not needed } & \multirow{2}{*}{$\mathrm{Y}$} & Count & 31 & 38 & 12 & 81 \\
\hline & & $\%$ within Number of Occupants & $21.7 \%$ & $29.2 \%$ & $37.5 \%$ & $26.6 \%$ \\
\hline & \multirow{2}{*}{$\mathrm{N}$} & Count & 112 & 90 & 20 & 222 \\
\hline & & $\%$ within Number of Occupants & $78.3 \%$ & $69.2 \%$ & $62.5 \%$ & $72.8 \%$ \\
\hline & \multirow{2}{*}{3} & Count & 0 & 1 & 0 & 1 \\
\hline & & $\%$ within Number of Occupants & $.0 \%$ & $.8 \%$ & $.0 \%$ & $.3 \%$ \\
\hline & \multirow{2}{*}{4} & Count & 0 & 1 & 0 & 1 \\
\hline & & $\%$ within Number of Occupants & $.0 \%$ & $.8 \%$ & $.0 \%$ & $.3 \%$ \\
\hline \multirow{2}{*}{ Total } & & Count & 143 & 130 & 32 & 305 \\
\hline & & $\%$ within Number of Occupants & $100.0 \%$ & $100.0 \%$ & $100.0 \%$ & $100.0 \%$ \\
\hline
\end{tabular}


Table 7. The Chi - Square Test on number of occupants in a household and the likelihood of leaving the appliances on when not in use.

\begin{tabular}{llll}
\hline & Value & df & Asymp. Sig. (2-sided) \\
\hline Pearson Chi-Square & $7.060^{\mathrm{a}}$ & 6 & .315 \\
Likelihood Ratio & 7.701 & 6 & .261 \\
Linear-by-Linear Association & 3.013 & 1 & .083 \\
N of Valid Cases & 305 & & \\
\hline
\end{tabular}

a. 6 cells $(50.0 \%)$ have expected count less than 5 . The minimum expected count is .10 .
The Chi - Square Test for the number of occupants in a household and the likelihood of leaving the appliances on when not in use was carried out, the result was a p-value of 0.315 Therefore $\mathrm{p}>0.05$ thus we reject the alternative hypothesis and fail to reject the null hypothesis. The number of occupants in a household does not relate to a higher probability of failing to put of appliances when they are not in use.

Table 8. Lights on when not needed vs Number of Occupants.

\begin{tabular}{|c|c|c|c|c|c|c|}
\hline & & & \multicolumn{3}{|c|}{ Number of Occupants } & \multirow{2}{*}{ Total } \\
\hline & & & $1-3$ & 4-6 & $>7$ & \\
\hline \multirow{6}{*}{ Lights on when not needed } & \multirow{2}{*}{ Y } & Count & 35 & 41 & 8 & 84 \\
\hline & & $\%$ within Number of Occupants & $24.5 \%$ & $31.5 \%$ & $25.0 \%$ & $27.5 \%$ \\
\hline & \multirow{2}{*}{$\mathrm{N}$} & Count & 108 & 88 & 24 & 220 \\
\hline & & $\%$ within Number of Occupants & $75.5 \%$ & $67.7 \%$ & $75.0 \%$ & $72.1 \%$ \\
\hline & \multirow{2}{*}{4} & Count & 0 & 1 & 0 & 1 \\
\hline & & $\%$ within Number of Occupants & $.0 \%$ & $.8 \%$ & $.0 \%$ & $.3 \%$ \\
\hline \multirow{2}{*}{ Total } & & Count & 143 & 130 & 32 & 305 \\
\hline & & $\%$ within Number of Occupants & $100.0 \%$ & $100.0 \%$ & $100.0 \%$ & $100.0 \%$ \\
\hline
\end{tabular}

Table 9. Chi-Square Tests.

\begin{tabular}{llll}
\hline & Value & df & Asymp. Sig. (2-sided) \\
\hline Pearson Chi-Square & $3.283^{\mathrm{a}}$ & 4 & .512 \\
Likelihood Ratio & 3.634 & 4 & .458 \\
Linear-by-Linear Association & .277 & 1 & .599 \\
N of Valid Cases & 305 & & \\
\hline
\end{tabular}

a. 3 cells $(33.3 \%)$ have expected count less than 5 . The minimum expected count is .10 .

The Chi - Square Test for the number of occupants in a household and the likelihood of leaving the appliances on when not in use was carried out, the result was a p-value of 0.512 Therefore $\mathrm{p}>0.05$ thus we reject the alternative hypothesis and fail to reject the null hypothesis. The number of occupants in a household does not relate to a higher probability of failing to put of lights when they are not in use.

\section{Conclusions and Recommendations}

The study set out to investigate the household factors that influence conservation and efficiency in electrical energy use among households of the Municipal Council of Nakuru houses The question asked was, what are the household factors influencing usage of electrical energy among households of the Nakuru Municipal houses? Among Household factors that influence efficiency is the number of occupants in a house. This study shows that the likelihood of leaving lights on or appliances is minimum when there are many occupants than when they are fewer $p$-value of 0.512 . The age of the household head has a positive small correlation (0.093) with possibility of leaving lights on and 0.061 for leaving appliances on so we can interpret that the older the person the higher the chances of leaving lights and appliances on. Level of education, income level have a small negative correlation for leaving lights and appliances of $-0.147,-0.114,-0.161$ and -0.165 . The foregoing can be interpreted that the more educated and the higher the income the less likelihood of leaving the lights and appliances. Interestingly gender has a negative small correlation for lights on when not needed, and a positive small correlation for appliances.

The study further found out that $70.8 \%$ of respondents indicated that they are cognizant of the fact that there exist other complementary and alternative sources of energy to electricity. $88.9 \%$ preferred solar although they mentioned that capital cost of installation is prohibitive. $60.3 \%$ who preferred fuel/kerosene also mentioned of fluctuations in prices and that it has high risk of fire. Charcoal was preferred by $80.3 \%$ and they mentioned prohibitive price, risk of suffocation, and environmental concerns as key shortcomings of charcoal. The study recommends that a similar study may be carried out but for owned residential houses where the household has control over the kind of installation he would want to install.

\section{References}

[1] Allingham, M. (2002). Choice Theory: A Very Short Introduction, Oxford University Press.

[2] Balla, P. (2006) National Study on Small Hydropower Development: Status and Potential of Small Hydropower Development in the Tea Industry in Kenya, unpublished report, Nairobi and Mombasa, UNEP/GEF and East African Tea Trade Association (EATTA)

[3] Basa, G. S. \& Princess J. T. M. (2009). Energy Conservation Practices in Selected Households in Ald

[4] Bicchieri, C. (2003). "Rationality and Game Theory", in The Handbook of Rationality, The Oxford Reference Library of Philosophy, Oxford University Press

[5] Brandon, G. R. (1993). Factors Affecting the Relationship Between Expressions of Environmental Concern. Climate Africa Network 
[6] Buesing, J. (1980). The Energy Efficient Home of the Future. Cutting Energy Costs.

[7] CAN, (2004) Energy in the East African Community, Nairobi, Climate Network Africa (CAN).

[8] Cook, S. \& Berenberg, J. (1981). Approaches to encouraging conservation behavior: a review and conceptual framework. Journal of Social Issues 2(2)73-107.

[9] Daraga, A. (2005). Occasional Paper 26: Renewable in Kenya's Electricity Industry: A Review of Geothermal and Cogeneration Technologies, Nairobi, African Energy Policy Research Network

[10] Fishbein, M. \& Ajzen, I. (1975). Belief, Attitude, Intention and Behaviour. Reading, MA: Addison-Wesley.

[11] Gallup, G. \& Newport, F. (1990). Americans strongly in tune with purpose of Earth day. Gallup Poll van

[12] Houwelingen, J. \& van Raiij, W. (1989). The effect of goal-setting and daily electronic feedback on in-home energy use. Journal of Consumer Research 3(1)98-105.

[13] Goett, A.A. and Hudson, K. (2000). Customers' choice among retail energy suppliers: The Willingness-To-pay for service attributes. Energy Journal, 21 (4), 1-28.

[14] Government of Kenya (2004). Sessional Paper No.4 of 2004 on Energy, Nairobi, Government of Kenya (GOK)

[15] Government of Kenya (2006) Code of Regulations (Revised), Director of Personnel Management.

[16] Gwendolyn \& Allan, L. (1999) Reducing Household Energy Consumption: A Qualitative and Quantitative Field Study. Journal of Environmental Psychology, 2 (3) 83-92

[17] Ester, P. (1985). Consumer Behaviour and Energy Conservation. Dordrecht

[18] Farhar, B. C. \& Fitzpatrick, C. (1989). Effects of Feedback on Residential Electricity Consumption: a literature review. Solar Energy Research Institute, US Department of Energy.

[19] Chapman, P. (2009) Warm Homes: Drivers of the Demand for Heating in the Residential Sector in New Zealand. Energy policy, 37, (9)3387-99

[20] Hutton, R. B., Mauser, G. A., Filiatrault, P. \& Ahtola, O. T. (1986). Effects of cost related feedback on consumer

[21] Jadresic, A. (2000). Promoting private investment in rural electrification- The case of Chile. Private Sector and Infrastructure Network Note number 214. World Bank, Washington, DC

[22] Joerges, B. \& Muller, H. (1983). Energy conservation programs for consumers: a comparative analysis of policy conflicts and program results in eight western countries. Journal of Economic Psychology, 3 (1) 35-42

[23] Karekezi K. (2005). Sustainable Energy in Africa: Cogeneration and Geothermal in the East and Horn of Africa Status and Prospects, Nairobi, AFREPREN/FWD

[24] Karekezi, S. (2002). 'Renewables in Africa - Meeting the Energy Needs of the Poor', Energy Policy, (30)11-12. Special Issue - Africa: Improving Modern Energy Service for the Poor, Oxford, Elsevier Ltd
[25] Kasulis, J. J., Huettner, D. A. \& Dikeman, N.J. (1981).The feasibility of changing electricity consumption patterns. Journal of Consumer Research 279]290.

[26] Kenya Institute for Public Policy Research and Analysis (2010) (KIPPRA) A comprehensive Study and Analysis on Energy Consumption Patterns in Kenya

[27] Kenya Integrated Household Budget Survey (KIHBS), (2007). Volume 1 basic report, 2005/06. Ministry of Planning and National Development (MoPND), Nairobi, Kenya

[28] Kenya Pipeline Company Ltd (2006). A Report on Current and Projected Consumption and Demand of Petroleum Products in the Great Lakes Region. 28th April 2006. KPC: Nairobi.

[29] Kluger, A. \& DeNisi, A. (1996). The effects of feedback interventions on performance: a historical review, a meta-analysis, and a preliminary feedback intervention theory. Psychological Bulletin, 254]284.

[30] KPLC (2006).Annual Report, 2006, Nairobi, Kenya Power and Lighting Company (KPLC)

[31] Lea, S., Tarpy, R. \& Webley, P. (1987). The Individual In The Economy. Cambridge: C.U.P.

[32] Lewis, A., Webley, P. \& Furnham, A. (1995). The New Economic Mind: the social psychology of economic behavior. LondonrNew York: Harvesterr Wheatsheaf.

[33] Longo, A., Markandya, A., and Petrucci, M., 2008. The internalization of externalities in the production of electricity: Willingness to pay for the attributes of a policy for renewable energy. Ecological Economics, 67(1), 140-152

[34] McDougall, G., Claxton, J., Ritchie, B. \& Anderson, C. (1981). Consumer energy research: a review. Journal of Consumer Research 3430-354.

[35] MoE, (2002): Study on Kenya's Eenrgy Demand, Supply and Policy Strategy for Households, Small Scale Industries and Service Establishments, Nairobi, Ministry of Energy (MoE)

[36] Nandi, S. \& Bose, R.K. (2010). The Imperative of Efficient Energy Use in Cities: Analytical Approaches and Good Practices in Bose R.K. (ed.) Energy Efficient Cities: Assessment Tools and Benchmarking Practices, pp 1-19, The World bank, Washington D.C

[37] Orodho,J (2005). Elements of Education and Social Science Research Methods, Masola Publishers Nairobi.

[38] O’Sullivan, K. and Barnes, D.F. (2006). Energy policies and multitopic household surveys: Guidelines for questionnaire design in living standards measurement studies. Paper No. 17. Energy and Mining Sector Board Discussion Paper, ESMAP, Washington, DC.

[39] Otegbulu, Austin C. (2010). Energy Efficient Practice: A Focus On Residential Households, Department of Estate Management; University of Lagos

[40] Otivar. (2009). Energy Conservation Practices in Selected Households in Five Barangays in Legazpi City. Unpublished Undergraduate Thesis, College of Business, Economics and Management.

[41] Pallak, M., Cook, D. \& Sullivan, J. (1980). In L. Bickman Ed. Commitment and Energy Conservation. 
77 Maina Kairu et al: : Household Unit Factors and Efficient Electricity Use: A Review of Households in Nakuru Town Housing Estates

[42] Rabah, K.V.O, (2005). Integrated solar energy systems for rural electrification in. Renewable Energy, 30 (1), 23-42.

[43] Republic of Kenya (2001). Study on Kenya's Energy Demand, supply and Policy. Strategy for Households, Small-scale Industries and Service, Establishments. Nairobi: Government Printer.

[44] Ritchie, B., McDougall, G. \& Claxton, J. (1981). Complexities of household energy consumption and conservation.

[45] Roe, B., Teisl, M., Levy, A., and Russell, M., (2001). US consumers' willingness to pay for green electricity. Energy Policy, 29, 917-925.

[46] Sanghvi, A. and Barnes, D., (2001). Rural electrification: Lessons learned. World Bank Findings: Operational Quality and Knowledge Services, Africa Region Infrastructure 177. World Bank, Washington, DC.

[47] Van der Plas, R. J. and Hankins, M. (1998). Solar electricity in Africa: A reality. Energy Policy, 26, 295-305.
[48] Wamukonya, N., (2007). Solar home system electrification as a viable technology option for Africa's development, Energy Policy, 35, 6-14.

[49] Seligman, C., Kriss, M., Darley, J., Fazio, R. H., Beck, L. J. \& Pryor, J. B. (1979). Predicting summer energy consumption from homeowner's attitudes. Journal of Applied Social Psychology, 70-90.

[50] Southwick, C.H, (1976). Ecology and the quality of our environment $2^{\text {nd }}$ edition. D.Van Nostrad Company 450 west 33rd street, New York.

[51] Muma, B. O., Nyaoga, B. R., Matwere, B. R. and Nyambega, E. K. (2014). Green Supply Chain Management and Environmental Performance among Tea Processing Firms in Kericho County, Kenya. International Journal of Economics, Finance and Management Science 2(5) 270-276 